\title{
Optimization of triple-junction hydrogenated silicon solar cell nc-Si:H/a-Si:H/a-SiGe:H using step graded $\mathrm{Si}_{1-x} \mathrm{Ge}_{x}$ layer
}

\author{
Nji Raden Poespawati, Rizqy Pratama Rahman, Junivan Sulistianto, Retno Wigajatri \\ Purnamaningsih, Tomy Abuzairi \\ Department of Electrical Engineering, Universitas Indonesia, Indonesia
}

\begin{tabular}{l} 
Article Info \\
\hline Article history: \\
Received Sep 28, 202 \\
Revised Dec 14, 2020 \\
Accepted Jan 15, 202 \\
\hline Keywords: \\
Hydrogenated silicon $_{\text {Si }}{ }_{1-x}$ Ge \\
Solar cell \\
Step graded \\
Triple-junction
\end{tabular}

\begin{abstract}
This paper shows the attempt to increase the performance of triple-junction hydrogenated silicon solar cells with structure nc-Si:H/a-Si:H/a-SiGe:H. The wXAMPS software was used to simulate and optimize the design. In an attempt to increase the performance, an a-SiC:H layer on the $p$-layer was replaced with an a-Si:H layer and an a-SiGe layer was replaced with a step graded $\mathrm{Si}_{1-x} \mathrm{Ge}_{x}$ layer. Then, to achieve the best performing device, we optimized the concentration of germanium and thickness of the step graded $\mathrm{Si}_{1-x} \mathrm{Ge}_{x}$ layer. The result shows that the optimum concentration of germanium in the p-i upper layer and i-n lower layer are 0.86 and 0.90 , respectively and the optimum thicknesses are $10 \mathrm{~nm}$ and $230 \mathrm{~nm}$, respectively. The optimized device performed with an efficiency of $19.08 \%$, adding 3 more percent of efficiency from the original design. Moreover, there is a significant possibility of increasing the efficiency of a triplejunction solar cell by modifying it into a step graded $\mathrm{Si}_{1-x} \mathrm{Ge}_{x}$ layer.
\end{abstract}

This is an open access article under the CC BY-SA license.

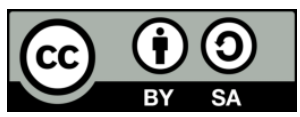

\section{Corresponding Author:}

Nji Raden Poespawati

Department of Electrical Engineering

Universitas Indonesia

Faculty of Engineering, Kampus UI Depok, Depok 16424, Indonesia

Email: pupu@eng.ui.ac.id

\section{NOMENCLATURE}

\begin{tabular}{lll}
\hline Symbols & Units & Description \\
\hline $\mathrm{E}_{\mathrm{g}}$ & $\mathrm{eV}$ & Mobility bandgap \\
$I_{S C}$ & $\mathrm{~mA}$ & Short-circuit current \\
$\mathrm{L}$ & $\mathrm{nm}$ & Layer thickness \\
$\mathrm{N}_{\mathrm{a}}$ & $\mathrm{cm}^{-3}$ & Acceptor doping concentration \\
$\mathrm{N}_{\mathrm{C}}$ & $\mathrm{cm}^{-3}$ & Effective conduction bands concentration \\
$\mathrm{N}_{\mathrm{d}}$ & $\mathrm{cm}^{-3}$ & Donor doping concentration \\
$\mathrm{N}_{\mathrm{V}}$ & $\mathrm{cm}^{-3}$ & Effective valence bands concentration \\
$\mu_{\mathrm{n}}$ & $\mathrm{cm}^{2} / \mathrm{Vs}$ & Electron mobility \\
$\mu_{\mathrm{p}}$ & $\mathrm{cm}^{2} / \mathrm{Vs}$ & Hole mobility \\
$V_{O C}$ & $\mathrm{~V}$ & Open-circuit voltage \\
$x$ & unitless & Mole fraction \\
\hline
\end{tabular}

\section{INTRODUCTION}

In the development of solar cell technology, multijunction (MJ) solar cells are standardly used to increase efficiency. In contrast to a single-junction solar cell, an MJ solar cell is made by stacking several semiconductor junctions, which allow a wider range of wavelengths to be converted into electricity. Recent 
progress in MJ solar cells, especially with semiconductor material III-V, has the potential to achieve conversion efficiencies of more than 40\% [1-3]. However, the common use of MJ solar cells with III-V materials is still limited due to the high cost of its fabrication and the rare materials used. To overcome these limitations, different design approaches and materials are needed. One of the solutions is the integration of semiconductor material III-V on a low-cost Si substrate. The development of III-V/Si can significantly reduce the cost of solar cells without reducing its efficiency $[4,5]$.

MJ solar cells are not limited to III-V material. Hydrogenated amorphous silicon-germanium (a-SiGe:H) is another potential thin-film material for MJ silicon solar cells. Theoretically, by using SiGe alloy, the absorption ability of silicon cells can be expanded to the infrared response and hence can increase the current generation [6]. A thin-film triple-junction cell that combines hydrogenated amorphous silicon (a-Si:H) and an a-SiGe:H can achieve a stable cell efficiency of 13\% [7]. Several groups also studied the triple-junction solar cell with structure a-Si:H/a-SiGe:H/nc-Si:H and can produce cells with an efficiency of $15.4 \%[8,9]$. Furthermore, modeling of MJ solar cells using a-SiGe:H and microcrystalline silicon were conducted [10]. Another effort to produce high-efficiency cells was performed by Ferhati et al. Incorporating muti-trench region shows an increase in the efficiency of a-SiGe:H MJ solar cells [11, 12]. Besides optimizing the device design, improving the quality of a-SiGe: $\mathrm{H}$ in the fabrication process can also resulting in a high-performance solar cell $[13,14]$.

However, the mentioned research did not apply the step graded $\mathrm{Si}_{1-x} \mathrm{Ge}_{x}$ to their structure. Silicon and germanium have a difference in their lattice constants, i.e. by $4.2 \%[15,16]$. This difference can cause a lattice mismatch, which causes a discontinuity in the SiGe layers embedded on a layer of silicon [17]. These discontinuities may create misfit dislocation defects and reduce the performance of solar cells [18]. To reduce these defects, the SiGe can be performed in stages based on the germanium concentration (step graded $\mathrm{Si}_{1-x} \mathrm{Ge}_{x}$ ). The step graded layer that is added to the silicon solar cells can improve the efficiency of the cells $[19,20]$. Furthermore, this technique can produce a layer of SiGe with better dislocation density, i.e. $10^{5} \mathrm{~cm}^{-2}$, compared to without using the grading step, which amounts to $10^{12} \mathrm{~cm}^{-2}$ [21]. In the recent development, the concept of reverse graded $\mathrm{SiGe}$ is introduced for GaAsP/SiGe tandem solar cells [22].

Here, we optimize the triple-junction solar cells of nc-Si:H/a-Si:H/a-SiGe:H which is based on our previous works [23]. The structure still using bulk a-SiGe:H which has a significant lattice constant mismatch. By replacing the a-SiGe:H layer with step graded $\mathrm{Si}_{1-x} \mathrm{Ge}_{x}: \mathrm{H}$ and replacing the a-SiC:H layer with an a-Si:H can improve the lattice constant mismatch, thus increasing its performance. Computer software wxAMPS was utilized to simulate and optimize the design [24]. To obtain the best performing device, we optimize the concentration and thickness of the step graded $\mathrm{Si}_{1-x} \mathrm{Ge}_{x}$ layer. Analysis of the bandgap and generation-recombination graph is also provided.

\section{DEVICE DESIGN AND OPTIMIZATION}

The original structure was optimized by searching the optimum thickness of the active layer, which resulted in a device with an efficiency of $15.73 \%$ [23]. To increase its efficiency further, we optimized the device structure in three stages, as shown in Figure 1. Additionally, flowchart of the optimization process can be found in Figure 2.

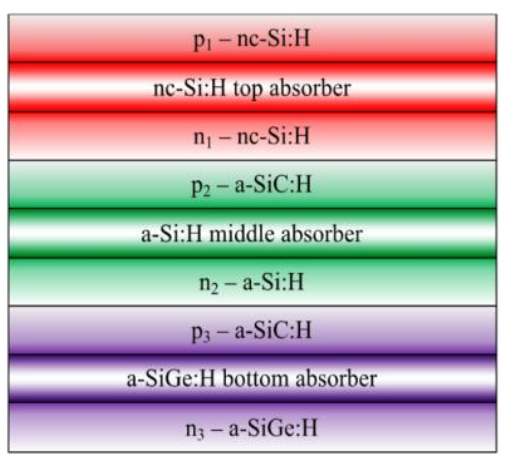

(a)

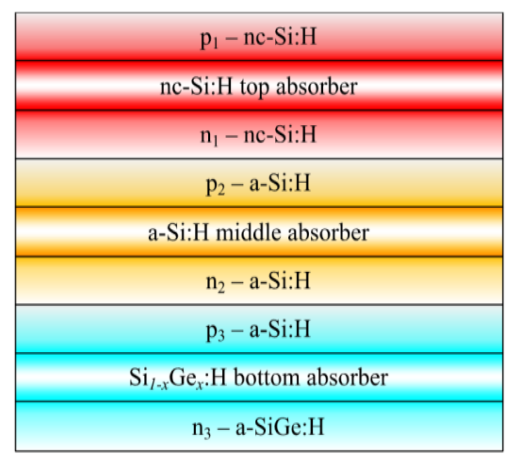

(b)

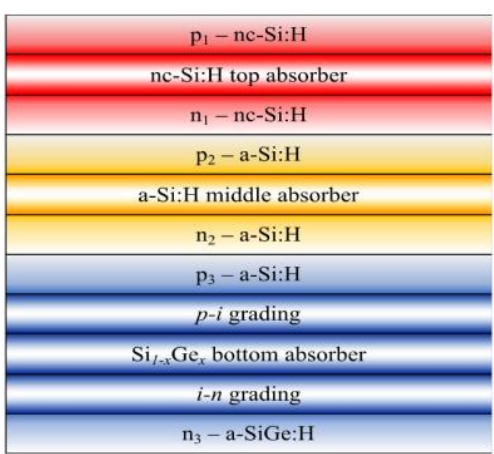

(c)

Figure 1. Three structures of the triple-junction solar cell used in this research, (a) The original structure (nc-Si:H/a-Si:H/a-SiGe:H), (b) The first and second stages of the optimization structure, (c) The third stage of the optimization structure using step grading 


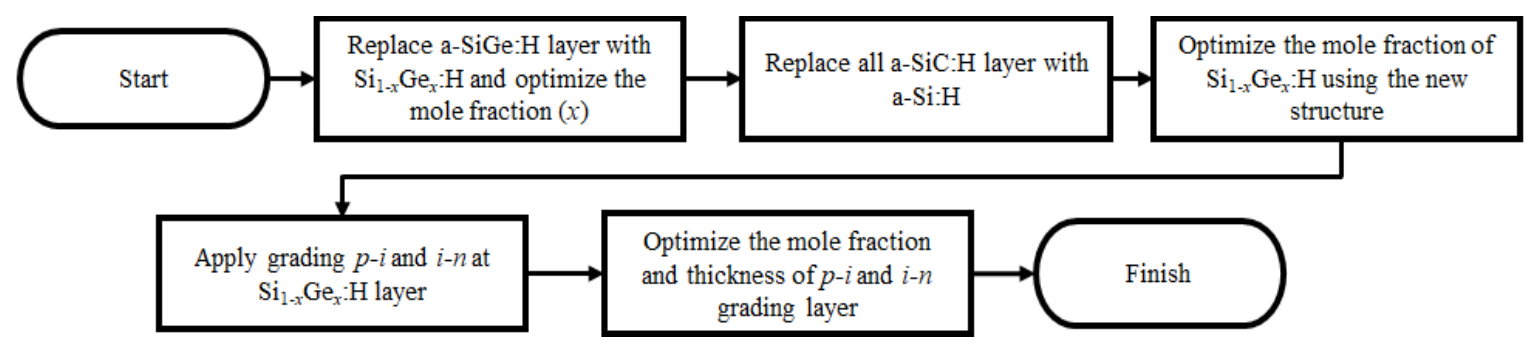

Figure 2. Flowchart of optimization process

First, the active layer compound of a-SiGe:H is replaced with the $\mathrm{Si}_{1-x} \mathrm{Ge}_{x}$ alloy with a Ge concentration of $50 \%$, This was conducted in consideration of the result by Ruiz et al. where $50 \%$ of Ge concentration is optimal for bulk devices [25]. Then, the active layer of $\mathrm{Si}_{1-x} \mathrm{Ge}_{x}$ is graded based on its mole fraction concentration. The alloy is varied with Ge concentrations from $86 \%$ to $90 \%$ because it is the most optimal concentration for the $\mathrm{Si}_{1-x} \mathrm{Ge}_{x}$ alloy [6]. For the optical parameter, $\mathrm{Si}_{1-x} \mathrm{Ge}_{x}$ with $\mathrm{Ge}$ concentration of $50 \%$ uses the absorption coefficient of $\mathrm{Si}_{1-x} \mathrm{Ge}_{x}$ with mole fraction $(x)$ of 0.50 , while $\mathrm{Si}_{1-x} \mathrm{Ge}_{x}$ with $\mathrm{Ge}$ concentration of $86 \%-90 \%$ uses absorption coefficient of $\mathrm{Si}_{1-x} \mathrm{Ge}_{x}$ with $x=1.00$ [26]. The electrical parameters of the $\mathrm{Si}_{1-x} \mathrm{Ge}_{x}$ layer that were used in this step are presented in Table 1, and a few of them were calculated using the following equations:

Permittivity(x) [27]:

$$
11.7+4.5 x
$$

Bandgap energy $\left(\mathrm{E}_{\mathrm{g}}\right)(x)[28]$ :

$$
\begin{aligned}
& 1.12-0.41 \mathrm{x}+0.008 x^{2} \text { eV for } x<0.85 \\
& 1.86-1.2 x \text { eVfor } x>0.85
\end{aligned}
$$

Effective conduction/valence band concentration $\left(\mathrm{N}_{\mathrm{C}} / \mathrm{N}_{\mathrm{V}}\right)[28]$ :

$$
\begin{aligned}
& \sim 2.8 \times 10^{19} \mathrm{~cm}^{-3} \quad \text { for } \mathrm{x}<0.85 \\
& \sim 1.0 \times 10^{19} \mathrm{~cm}^{-3} \quad \text { for } \mathrm{x}>0.85
\end{aligned}
$$

Electron affinity $(\chi)(x)[29]$ :

$$
4.05-0.05 x \mathrm{eV}
$$

Electron mobility $\left(\mu_{n}\right)(x)[30]$ :

$$
1500(1-x)+3900 x \mathrm{~cm}^{2} / \mathrm{Vs}^{-1}
$$

Hole mobility $\left(\mu_{\mathrm{p}}\right)(x)[30]$ :

$$
450(1-x)+1900 x \mathrm{~cm}^{2} / \mathrm{Vs}^{-1}
$$

Table 1. Electrical parameters of $\mathrm{Si}_{1-x} \mathrm{Ge}_{x}$ layer

\begin{tabular}{cccccccc}
\hline $\mathrm{x}$ & Permittivity & $\begin{array}{c}\mathrm{E}_{\mathrm{g}} \\
(\mathrm{eV})\end{array}$ & $\begin{array}{c}\text { Affinity } \\
(\mathrm{eV})\end{array}$ & $\mathrm{N}_{\mathrm{C}}\left(\mathrm{cm}^{-3}\right)$ & $\mathrm{N}_{\mathrm{V}}\left(\mathrm{cm}^{-3}\right)$ & $\begin{array}{c}\mu_{\mathrm{n}} \\
\left(\mathrm{cm}^{2} / \mathrm{V}-\mathrm{s}\right)\end{array}$ & $\begin{array}{c}\mu_{\mathrm{p}} \\
\left(\mathrm{cm}^{2} / \mathrm{V}-\mathrm{s}\right)\end{array}$ \\
\hline 0.50 & 13.950 & 0.917 & 4.0250 & $2.8 \times 10^{19}$ & $2.8 \times 10^{19}$ & 2700 & 1175 \\
0.86 & 15.570 & 0.828 & 4.0070 & $1.0 \times 10^{19}$ & $1.0 \times 10^{19}$ & 3564 & 1697 \\
0.87 & 15.615 & 0.816 & 4.0065 & $1.0 \times 10^{19}$ & $1.0 \times 10^{19}$ & 3588 & 1711.5 \\
0.88 & 15.660 & 0.804 & 4.0060 & $1.0 \times 10^{19}$ & $1.0 \times 10^{19}$ & 3612 & 1726 \\
0.89 & 15.705 & 0.792 & 4.0055 & $1.0 \times 10^{19}$ & $1.0 \times 10^{19}$ & 3636 & 1740.5 \\
0.90 & 15.750 & 0.780 & 4.0050 & $1.0 \times 10^{19}$ & $1.0 \times 10^{19}$ & 3660 & 1755 \\
\hline
\end{tabular}


Second, replacing the a-SiC layer on the $p$-layers of the middle and bottom junctions with a-Si. This replacement is based on the lattice constants of the materials. The a-SiC layer has a lattice constant of 3.073 $\AA$, whereas a-Si has a lattice constant of 5.431 $\AA$. Since a-Si has a lattice constant closer to its neighbor materials, the replacement of the a-SiC layer with a-Si reduces misfit dislocation and increases the overall efficiency of the solar cells. After all of the a-SiC layer is replaced with a-Si, the simulation is again performed with varying $\mathrm{Si}_{1-x} \mathrm{Ge}_{x}$ layers with Ge concentrations between $86 \%$ and $90 \%$.

Finally, the $\mathrm{Si}_{1-x} \mathrm{Ge}_{x}$ active layer at the bottom of the cell is graded with the $p$ - $i$ layer grading on top (thickness $10 \mathrm{~nm}$ ) and the $i$ - $n$ layer grading at the bottom (thickness varying from $10 \mathrm{~nm}$ to $360 \mathrm{~nm}$ ). The final structure can be seen in Figure 1(c). The choice of thickness is referring to experiments conducted by Swaaij et al. [19]. To optimize the solar cell efficiency, the grading width of the $p-i$ interface should be as small as possible, while the $i$ - $n$ interface should be as large as possible. The electrical parameters of the solar cell structure can be seen in Table 2 .

Table 2. Electrical parameters of the triple-junction solar cell when grading $\mathrm{Si}_{1-x} \mathrm{Ge}_{x}$ bottom absorber layer

\begin{tabular}{|c|c|c|c|c|c|c|c|c|c|c|c|}
\hline \multirow{3}{*}{$\begin{array}{c}\text { Layer } \\
\text { parameters }\end{array}$} & \multicolumn{11}{|c|}{ Solar cell layers } \\
\hline & $\mathrm{p}$ & $\mathrm{i}$ & $\mathrm{n}$ & $\mathrm{p}$ & $\mathrm{i}$ & $\mathrm{n}$ & $\mathrm{p}$ & $\begin{array}{c}\mathrm{p}-\mathrm{i} \\
\text { grading }\end{array}$ & $\mathrm{i}$ & $\begin{array}{c}\mathrm{i}-\mathrm{n} \\
\text { grading }\end{array}$ & $\mathrm{n}$ \\
\hline & nc-Si:H & nc-Si:H & nc-Si:H & a-Si:H & a-Si:H & $\mathrm{a}-\mathrm{Si}: \mathrm{H}$ & $\mathrm{a}-\mathrm{Si}: \mathrm{H}$ & $\begin{array}{l}\mathrm{Si}_{1-x} \mathrm{Ge}_{x} \\
x=0.86\end{array}$ & $\begin{array}{l}\mathrm{Si}_{1-x} \mathrm{Ge}_{x} \\
x=0.86\end{array}$ & $\begin{array}{l}\mathrm{Si}_{1-x} \mathrm{Ge}_{x} \\
x=0.90 \\
\end{array}$ & $\begin{array}{c}\text { a- } \\
\text { SiGe:H }\end{array}$ \\
\hline $\mathrm{L}(\mathrm{nm})$ & 10 & 2100 & 25 & 10 & 90 & 25 & 10 & 10 & $370-w$ & $\mathrm{w}$ & 25 \\
\hline Permittivity & 11.9 & 11.9 & 11.9 & 11.9 & 11.9 & 11.9 & 11.9 & 15.57 & 15.57 & 15.75 & 14 \\
\hline $\mathrm{E}_{\mathrm{g}}(\mathrm{eV})$ & 2 & 1.95 & 1.95 & 1.82 & 1.82 & 1.82 & 1.82 & 0.828 & 0.828 & 0.78 & 1.4 \\
\hline $\mathrm{N}_{\mathrm{V}}\left(\mathrm{cm}^{-3}\right)$ & $2.5 \times 10^{20}$ & $2.5 \times 10^{20}$ & $2.5 \times 10^{20}$ & $2.5 \times 10^{20}$ & $2.5 \times 10^{20}$ & $2.5 \times 10^{20}$ & $2.5 \times 10^{20}$ & $1 \times 10^{19}$ & $1 \times 10^{19}$ & $1 \times 10^{19}$ & $1 \times 10^{20}$ \\
\hline$\mu_{\mathrm{n}}\left(\mathrm{cm}^{2} / \mathrm{Vs}\right)$ & 850 & 2000 & 850 & 20 & 20 & 20 & 20 & 3564 & 3564 & 3660 & 60 \\
\hline$\mu_{\mathrm{p}}\left(\mathrm{cm}^{2} / \mathrm{Vs}\right)$ & 350 & 400 & 350 & 2 & 2 & 2 & 2 & 1697 & 1697 & 1755 & 10 \\
\hline $\mathrm{N}_{\mathrm{d}}\left(\mathrm{cm}^{-3}\right)$ & 0 & 0 & $8 \times 10^{18}$ & 0 & 0 & $8 \times 10^{18}$ & 0 & 0 & 0 & 0 & $1 \times 10^{19}$ \\
\hline $\mathrm{N}_{\mathrm{a}}\left(\mathrm{cm}^{-3}\right)$ & $3 \times 10^{18}$ & 0 & 0 & $3 \times 10^{18}$ & 0 & 0 & $3 \times 10^{18}$ & 0 & 0 & 0 & 0 \\
\hline
\end{tabular}

\section{RESULTS AND DISCUSSION}

In the first stage, the result of a triple-junction solar cell simulation with the structure nc-Si:H/ a-Si:H/Si $i_{1-x} \mathrm{Ge}_{x}: \mathrm{H}$ shows that the $\mathrm{Si}_{1-x} \mathrm{Ge}_{x}$ layer with the mole fraction $x=0.89$ has not only the best efficiency but also the best fill factor (FF). It also confirms that the optimum concentration of germanium in the $\mathrm{Si}_{1-x} \mathrm{Ge}_{x}$ alloy is between $86 \%$ and $90 \%$ [6]. The changes in efficiency related to the Ge mole fraction are shown in Figure 3.

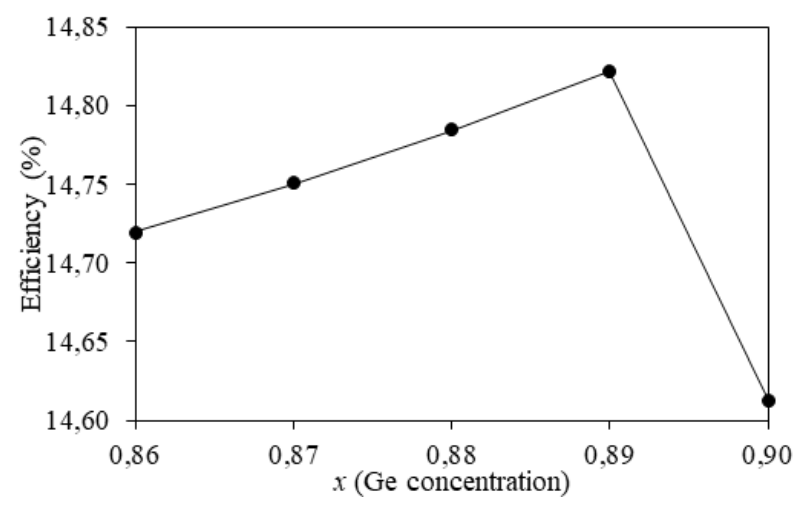

Figure 3. Efficiency versus Ge concentration for the first stage of optimization

The simulation results of the second optimization show that $90 \%$ germanium concentration in the $\mathrm{Si}_{1-x} \mathrm{Ge}_{x}$ layer produces the solar cell's highest efficiency. Figure 4 shows the changes in efficiency related to Ge mole fraction in a-Si configuration. The efficiency curve is also still in accordance with result from Koschier et al. [6]. The numbers show that the replacement of a-SiC with a-Si can reduce the misfit dislocation, which, in turn, can increase the FF of the solar cells as well as its efficiency. Misfit dislocation 
reduction is seen in lattice constant difference when using a-SiC and after it is replaced with a-Si. In the middle junction, the lattice constant of a-SiC has a difference of $2.358 \AA$ compared to both the nc-Si and a-Si layers. In the lower junction, the lattice constant of a-SiC has a difference of $2.557 \AA$ relative to the $\mathrm{Si}_{1-x} \mathrm{Ge}_{x}$ layer, while the a-Si lattice constant differs by only $0.199 \AA$ (less than $4.2 \%$ ) from the $\mathrm{Si}_{1-x} \mathrm{Ge}_{x}$ layer. In the third stage, in theory, the addition of a grading layer on the active layer of $\mathrm{Si}_{1-x} \mathrm{Ge}_{x}$ will affect the efficiency of solar cells in terms of the addition of the FF [19].

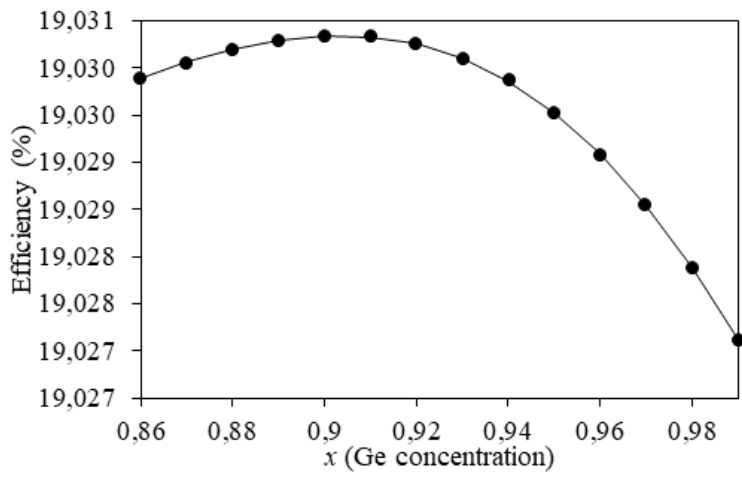

Figure 4. Efficiency versus Ge concentration for the second stage of optimization

This can be proven by the curves of the solar cells' open-circuit voltage $\left(V_{O C}\right)$ and short-circuit current $\left(I_{S C}\right)$ parameter values, which do not change when the grading thickness is varied in the $\mathrm{Si}_{1-x} \mathrm{Ge}_{x}$ layer, see Figures 5(a)-(b). The final result for the thickness used for the $i$ - $n$ grading layer is $230 \mathrm{~nm}$, since the highest efficiency is produced at this thickness despite the FF generated is equal to the thickness of $200 \mathrm{~nm}$ to 240 nm, see Figures 5(c)-(d).

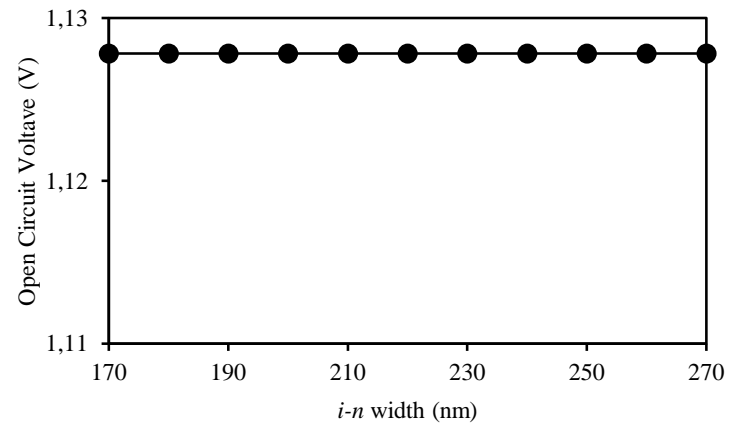

(a)

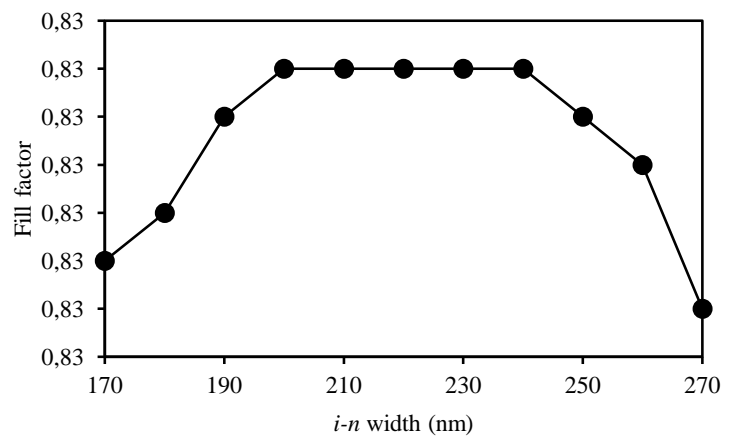

(c)

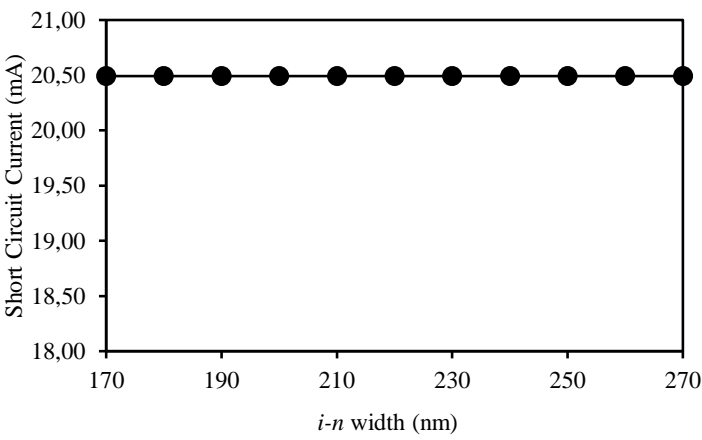

(b)

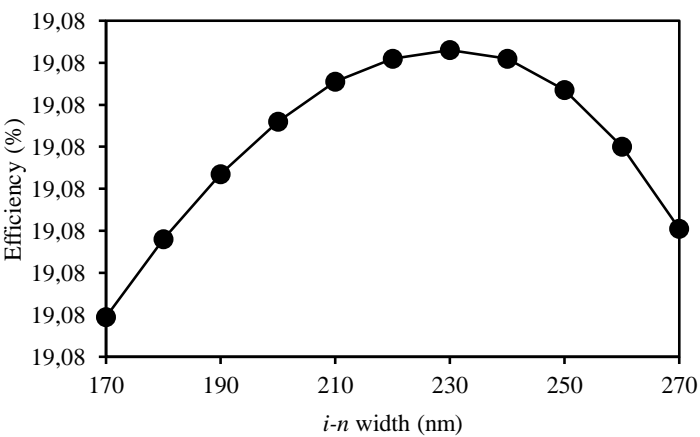

(d)

Figure 5. Photovoltaic parameter versus $i$ - $n$ width for grading layer of $\mathrm{Si}_{1-x} \mathrm{Ge}_{x}$, (a) $V_{O C}$, (b) $I_{S C}$, (c) FF, (d) Efficiency 
Thus, the germanium mole fraction $x$ obtained for the optimum composition of the $p$ - $i$ upper layer and the $i$-n lower layer is 0.86 with a thickness of $10 \mathrm{~nm}$ and 0.90 with a thickness of $230 \mathrm{~nm}$, respectively. The magnitude of the $I_{S C}$ produced by the triple-junction solar cell nc-Si:H/a-Si:H/Si ${ }_{1-x} \mathrm{Ge}_{x}: \mathrm{H}$ is $20.49 \mathrm{~mA}$, the $V_{O C}$ is $1.13 \mathrm{~V}$, and the FF is 0.83 , allowing the solar cell efficiency to reach $19.08 \%$. The final results show that there is a significant possibility of increasing the efficiency of a triple-junction solar cell with the structure nc-Si:H/a-Si:H/Si ${ }_{1-x} \mathrm{Ge}_{\mathrm{x}}: \mathrm{H}$ by modifying it into a step graded $\mathrm{Si}_{1-\mathrm{x}} \mathrm{Ge}_{\mathrm{x}}$ layer. The improvement of the solar cell performance for each stage is summarized in Table 3.

Table 3. Best solar cell performance for every stage of optimization

\begin{tabular}{ccccc}
\hline Stage & $V_{O C}(\mathrm{~V})$ & $I_{S C}(\mathrm{~mA})$ & FF & Efficiency $(\%)$ \\
\hline 1 & 1.13 & 20.49 & 0.64 & 14.82 \\
2 & 1.13 & 20.49 & 0.82 & 19.03 \\
3 & 1.13 & 20.49 & 0.83 & 19.08 \\
\hline
\end{tabular}

To give an understanding of the junction, the energy band diagram of the optimized device is presented in Figure 6. The top and bottom black lines are the valence and conduction band, respectively. The red line is the quasi-Fermi level for the holes, and the blue line is the quasi-Fermi level for the electrons. The blue lines indicated that the movement of electrons from the upper to the lower cells does not show any resistance. Usually, the resistance will occur in the junction caused by the barrier between the junctions. The lack of resistance can be caused by the thin $n-p$ interface layers and the large doping difference at the $n-p$ interface of junctions make inter-junction barriers function as a tunnel junction, which resulted in the electron traversed via this tunnel.

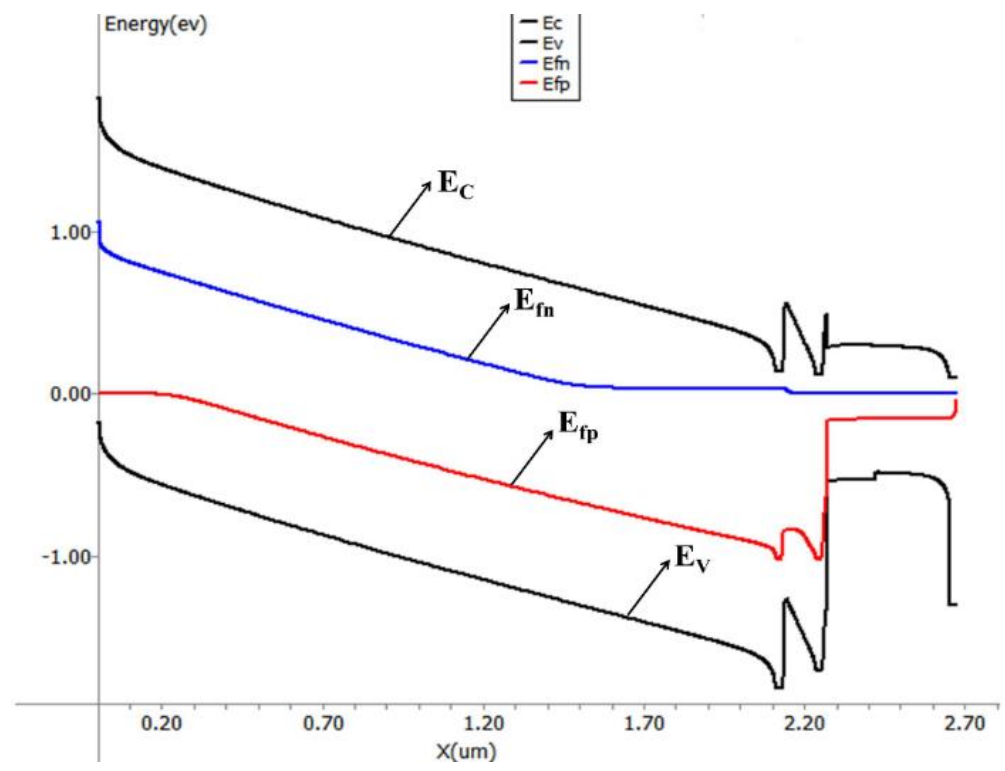

Figure 6. Energy band diagram of the triple-junction solar cell nc-Si:H/a-Si:H/Si ${ }_{1-x} \mathrm{Ge}_{x}: \mathrm{H}$

From a graph of recombination-generation (R-G), it can be seen there is a high rate of recombination at the interface of each cell, see Figure 7. This is one of the main problems in multijunction solar cells. At the interface of the upper and middle cells, the recombination surpasses the generations, so it can be regarded as a loss factor. Recombination also occurs in the middle and lower cell interface, but it is not surpassing the generation. The rising levels of recombination at the bottom of the cell area (below 0.3 $\mu \mathrm{m})$ may be caused by the unevaluated $n$-type a-SiGe:H characteristics. However, this also shows that the addition of step-grading above the $n$-type a-SiGe:H layer can minimize the lattice mismatch. Despite significant increases in overall performance, the R-G graph shows a prospect of future research to suppress the recombination level on this structure. 


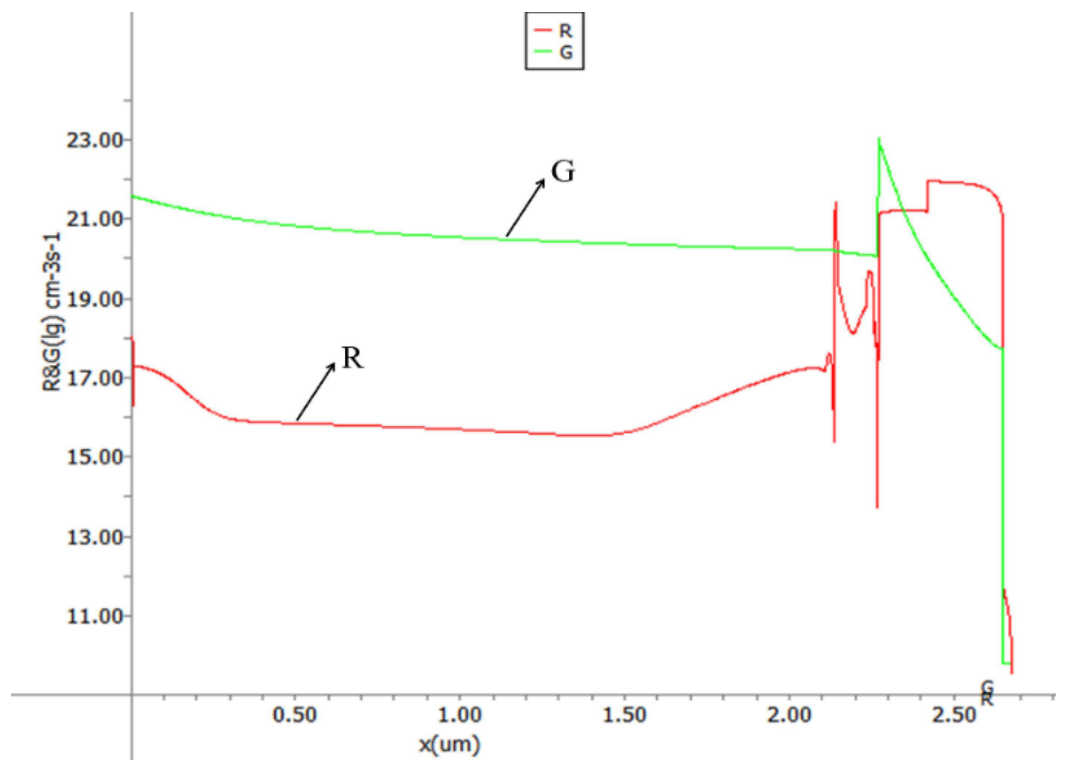

Figure 7. Recombination and generation of the triple-junction solar cell nc-Si:H/a-Si:H/Si ${ }_{1-x} \mathrm{Ge}_{x}: \mathrm{H}$

\section{CONCLUSION}

The design and optimization of a triple-junction solar cell with the structure nc-Si:H/a-Si:H/Si ${ }_{1-x} \mathrm{Ge}_{x}: \mathrm{H}$ can increase efficiency as compared to the original design of the solar cell. In the first stage, the replacement of a-SiGe:H with $\mathrm{Si}_{1-x} \mathrm{Ge}_{x}$ gives the optimum mole fraction of Ge. Using the Ge mole fraction $x=0.89$, the solar cell achieves its best performance with an efficiency of $14.82 \%$. In the second stage, the replacement of a-SiC with a-Si successfully increases solar cell performance with an efficiency of $14.03 \%$. Furthermore, it was found the optimum Ge concentration using the second stage structure is $90 \%$. In the third stage, it was found that the optimum germanium mole fraction composition of the $p-i$ upper layer and $i-n$ lower layer at the step graded $\mathrm{Si}_{1-x} \mathrm{Ge}_{x}$ layer is 0.86 , and 0.90 , respectively, and the thicknesses are $10 \mathrm{~nm}$ and $230 \mathrm{~nm}$, respectively. The optimized structure produces a solar cell with $I_{S C}$ of $20.49 \mathrm{~mA}, V_{O C}$ of $1.13 \mathrm{~V}$, FF of 0.83 , and efficiency of $19.08 \%$.

\section{ACKNOWLEDGEMENTS}

This work was supported by the Ministry of Technology Research and Higher Education of the Republic of Indonesia under Grant Nr. NKB-354/UN2.RST/HKP.05.00/2020 and Directorate of Innovation and Science Techno Park Universitas Indonesia under Grant of Design and Prototyping Development P5 2020. The authors also acknowledge the support of the Engineering Faculty, Universitas Indonesia.

\section{REFERENCES}

[1] M. A. Green, E. D. Dunlop, J. Hohl-Ebinger, M. Yoshita, N. Kopidakis, and A. W. Y. Ho-Baillie, "Solar cell efficiency tables (Version 55)," Progress in Photovoltaics: Research and Applications, vol. 28, no. 1, pp. 3-15, 2020.

[2] M. S. Leite, R. L. Woo, J. N. Munday, W. D. Hong, S. Mesropian, D. C. Law, and H. A. Atwater, "Towards an optimized all lattice-matched InAlAs/InGaAsP/InGaAs multijunction solar cell with efficiency $>50 \%$," AIP Applied Physics Letters, vol. 102, no. 3, p.033901, 2013.

[3] K. Araki, Y. Ota, H. Saiki, H. Tawa, K. Nishioka, and M. Yamaguchi, "Super-multi-junction solar cells-device configuration with the potential for more than 50\% annual energy conversion efficiency (non-concentration)," Applied Sciences, vol. 9, no. 21, pp. 1-21, 2019.

[4] Y. Zhang and H. Liu, "Nanowires for high-efficiency, low-cost solar photovoltaics," Crystals, vol. 9, no. 87, pp. 1$25,2019$.

[5] S. Abdul Hadi, E. A. Fitzgerald, S. Griffiths, and A. Nayfeh, "III-V/Si dual junction solar cell at scale: Manufacturing cost estimates for step-cell based technology," AIP Journal of Renewable and Sustainable Energy, vol. 10, no. 1, p. 015905, 2018.

[6] L. M. Koschier, S. R. Wenham, and M. A. Green, "Modeling and optimization of thin-film devices with Si/sub 1x/Ge/sub x/ alloys," in IEEE Transactions on Electron Devices, vol. 46, no. 10, pp. 2111-2115, Oct 1999.

[7] J. Yang, A. Banerjee, and S. Guha, "Triple-junction amorphous silicon alloy solar cell with $14.6 \%$ initial and 13.0\% stable conversion efficiencies," AIP Applied Physics Letters, vol. 70, no. 22, pp. 2975-2977, 1997.

Optimization of triple-junction hydrogenated silicon solar cell nc-Si:H/a-Si:H/... (Nji Raden Poespawati) 
[8] X. Deng, X. Cao, Y. Ishikawa, W. Du, X. Yang, C. Das, and A. Vijh, "Fabrication and characterization of triplejunction amorphous silicon based solar cell with nanocrystalline silicon bottom cell," 2006 IEEE 4th World Conference on Photovoltaic Energy Conference, Waikoloa, HI, pp. 1461-1464, 2006.

[9] B. Yan, G. Yue, Y. Yan, C. S. Jiang, C. W. Teplin, J. Yang, and S. Guha, "Correlation of hydrogen dilution profiling to material structure and device performance of hydrogenated nanocrystalline silicon solar cells," Cambridge University Press, vol. 1066, p. 1066-A03-03, Feb. 2008.

[10] Y. G. Xiao, K. Uehara, M. Lestrade, Z. Q. Li, and Z. M. S. Li, "Modeling of SI-based thin film triple-junction solar cells," 2009 34th IEEE Photovoltaic Specialists Conference (PVSC), Philadelphia, PA, pp. 002154-002158, 2009.

[11] K. Kacha, F. Djeffal, H. Ferhati, D. Arar, and M. Meguellati, "Numerical investigation of a double-junction a:SiGe thin-film solar cell including the multi-trench region," Journal of Semiconductors, vol. 36, no. 6, pp. 1-5, 2015.

[12] H. Ferhati, F. Djeffal, K. Kacha, and D. Arar, "High efficiency amorphous triple-junction thin-film SiGe solar cells incorporating multi-trench region," 2015 4th International Conference on Systems and Control (ICSC), Sousse, pp. 274-277, 2015.

[13] G. Yue, B. Yan, J. Yang, and S. Guha, "Hydrogenated amorphous silicon and silicon germanium triple-junction solar cells at high rate using RF and VHF glow discharges," 2008 33rd IEEE Photovoltaic Specialists Conference, San Diego, CA, USA, pp. 1-6, 2008.

[14] X. Xu, D. Beglau, G. Pietka, S. Ehlert, T. Su, J. Zhang, Y. Li, K. Lord, G. Yue, B. Yan, A. Banerjee, "High efficiency large area a-SiGe:H based multi-junction solar cells using MVHF," Physica Status Solidi C, vol. 7, no. 34, pp. 1077-1080, 2010.

[15] M. Willander and S. Jain, "Silicon-germanium strained layers and heterostructures," Semi-conductor and semimetals series, 1st ed. California: Elsevier, 2003.

[16] Y. M. Haddara, P. Ashburn, and D. M. Bagnall, "Silicon-germanium: Properties, growth and applications," Springer Handbook of Electronic and Photonic Materials, pp. 1-1, 2017.

[17] K. Kacha, F. Djeffal, T. Bentrcia, M. Meguellati, and M. Chahdi, "Improving the efficiency of thin-film SiGe solar cells through the optimization of intrinsic layer parameters," Proceedings of the World Congress on Engineering, vol. 1, pp. 387-389, 2014

[18] L. K. Orlov, Z. J. Horvath, N. L. Ivina, V. I. Vdoin, E. A. Steinman, M. L. Orlov, and Y. A. Romanov, "Multilayer strained $\mathrm{Si} / \mathrm{SiGe}$ structures: Fabrication problems, interface characteristics, and physical properties," OptoElectronics Review, vol. 11, no. 2, pp. 169-174, 2003.

[19] R. A. C. M. M. van Swaaij, M. Zeman, S. Arnoult, and J. W. Metselaar, "Performance dependence on grading width of a-SiGe:H component solar cells," Conference Record of the Twenty-Eighth IEEE Photovoltaic Specialists Conference-2000 (Cat. No.00CH37036), Anchorage, AK, USA, pp. 869-872, 2000.

[20] H. J. Hsu, C. H. Hsu, and C. C. Tsai, "The effect of bandgap graded absorber on the performance of a-Si 1- xGex:H Single-Junction Cells with c-SiOx:H N-Type Layer," International Journal of Photoenergy, vol. 2013, no. 364638, pp. 1-6, 2013.

[21] S. Jain and M. Willander, "Silicon-germanium strained layers and heterostructures," 2nd ed. California: Academic Press, 2003.

[22] P. Caño, M. Hinojosa, H. Nguyen, A. Morgan, D. F. Marrón, I. García, A. Johnson, and I. Rey-Stolle, "Hybrid III$\mathrm{V} / \mathrm{SiGe}$ solar cells grown on Si substrates through reverse graded buffers," Solar Energy Materials and Solar Cells, vol. 205, p. 110246, 2020.

[23] T. Abuzairi and N. Raden Poespawati, "A simple optimization of triple-junction solar cell nc-Si:H/a-Si:H/a-SiGe:H using computer modeling and robust design," Advanced Materials Research, vol. 896, pp. 455-458, 2014.

[24] Y. Liu, Y. Sun, and A. Rockett, "A new simulation software of solar cells-wxAMPS," Solar Energy Materials and Solar Cells, vol. 98, pp. 124-128, 2012.

[25] J. M. Ruiz, J. Casado, and A. Luque, "Assessment of crystalline Si1-xGex infrared solar cells for dual bandgap PV concept," in 72th PVSEC, Amsterdam, pp. 572-574, 1994.

[26] Michael H. Jones and Stephen H. Jones, "Optical Properties of SiGe and Ge," Virginia Semiconductor.

[27] Ioffe Institute, "Basic parameters of silicon germanium (SiGe)." [Online]. Available at: http://www.ioffe.ru/SVA/NSM/Semicond/SiGe/basic.html. [Accessed: 12-May-2015].

[28] Ioffe Institute, "Silicon germanium (SiGe)-band structure." [Online]. Available at: http://www.ioffe.ru/SVA/NSM/Semicond/SiGe/bandstr.html. [Accessed: 12-May-2015].

[29] "The general properties of Si, Ge, SiGe, SiO2 and Si3N4," Virginia Semiconductor, 2002.

[30] A. K. Das, "Numerical simulation of SiGe thin film solar cell using AMPS-1D," IOSR Journal of Applied Physics (IOSR-JAP), vol. 7, no. 1, pp. 23-30, 2015. 